\title{
Th(IV)-Hexacyanoferrate Modified Carbon Paste Electrode as a New Electrocatalytic Probe for Simultaneous Determination of Ascorbic Acid and Dopamine from Acidic Media
}

\author{
Khalil Farhadi, ${ }^{* a}$ Farshad Kheiri ${ }^{a}$ and Mirmaqsoud Golzan ${ }^{b}$ \\ ${ }^{a}$ Department of Chemistry, Faculty of Science, Urmia University, Urmia, Iran \\ ${ }^{b}$ Department of Physics, Faculty of Science, Urmia University, Urmia, Iran
}

\begin{abstract}
A estabilidade do eletrodo de pasta de carbono (CPE) foi obtida com o par eletrônico do Th(IV)-hexaferrocianeto (Th-HCF) e seu comportamento eletroquímico foi investigada por voltametria cíclica. A constante aparente do meio heterogêneo (ks) e o coeficiente de transferência $(\alpha)$, do par eletrônico Th-HCF e CPE, foram calculados como 0,47 e 3,1 $\pm 0,1 \mathrm{~s}^{-1}$, respectivamente. A cobertura da superfície $(\Gamma)$ do presente eletrodo foi calculada como 7,06 $\times$ $10^{-10} \mathrm{~mol} \mathrm{~cm}{ }^{-2}$. O Th-HCF modificado com o eletrodo de pasta de carbono (THMCPE) apresentou um bom comportamento eletrocatalítico, com uma mudança significativa nos valores negativos do potenciais de oxidação do ácido ascórbico (AA) e da dopamina (DA), em meio ácido (solução tampão fosfato, $\mathrm{pH} 3$ ). O THMCPE mostrou também excelentes características para a determinação simultânea de AA e DA. As curvas amperométricas utilizando o presente catalisador são lineares para a DA e AA , na faixa de concentrações entre $8 \times 10^{-6}-2 \times 10^{-3} \mathrm{e} 1 \times 10^{-5}-2 \times 10^{-3} \mathrm{~mol} \mathrm{~L}^{-1}$, com limites de detecção de $5,6 \times 10^{-6} \mathrm{~mol} \mathrm{~L}^{-1}$ e $4,7 \times 10^{-6} \mathrm{~mol} \mathrm{~L}^{-1}$, respectivamente. Os coeficientes de difusão para o AA e DA, na oxidação electrocatalítica, foram calculados a partir dos dados de cronoamperometria.
\end{abstract}

\begin{abstract}
A stable carbon paste electrode (CPE) was prepared with Th(IV)-hexacyanoferrate (Th-HCF) ion pair and its electrochemical behavior was investigated by cyclic voltammetry. The apparent heterogeneous rate constant, $\mathrm{k}_{\mathrm{s}}$, and transfer coefficient, $\alpha$, for electron transfer between Th-HCF ion-pair and CPE were calculated as $3.1 \pm 0.1 \mathrm{~s}^{-1}$ and 0.47 , respectively. The surface coverage $(\Gamma)$ of the proposed electrode was calculated as $7.06 \times 10^{-10} \mathrm{~mol} \mathrm{~cm}^{-2}$. The proposed Th-HCF modified carbon paste electrode (THMCPE) showed a good electrocatalytic behavior with a significant shift toward negative potentials in oxidation of ascorbic acid (AA) and dopamine (DA) in acidic media (phosphate buffer solution, $\mathrm{pH}$ 3). The THMCPE exhibited excellent characteristics for simultaneous determination of AA and DA. Amperometric curves using the catalytic currents are linear for DA and AA concentrations in the ranges $8 \times 10^{-6}-2 \times 10^{-3}$ and $1 \times 10^{-5}-2 \times 10^{-3} \mathrm{~mol} \mathrm{~L}^{-1}$ with detection limits $5.6 \times 10^{-6} \mathrm{~mol} \mathrm{~L}^{-1}$ and $4.7 \times 10^{-6} \mathrm{~mol} \mathrm{~L}^{-1}$, respectively. Diffusion coefficients of AA and DA in electrocatalaytic oxidation were calculated from chronoamperometric data.
\end{abstract}

Keywords: modified carbon paste, Th(IV)-hexacyanoferrate, ascorbic acid, dopamine

\section{Introduction}

Modified carbon electrodes have been widely used as sensitive and selective sensors in various electroanalytical methods. Among the various mediators used for electrode modification, solid metal hexacyanoferrates (MHCFs) were used as suitable modifier due to excellent electron transfer properties. Therefore, various transition metal cations have been used with hexacyanoferrate to fabricate

*e-mail: khfarhadi@yahoo.com
MHCF modified electrodes, where M represents iron(III), ${ }^{1,2}$ cadmium, ${ }^{3}$ chromium, ${ }^{4}$ cobalt,${ }^{5-8}$ copper, ${ }^{9-12}$ gallium,,${ }^{13}$ indium, ${ }^{14,15}$ lanthanum, ${ }^{16}$, manganese, ${ }^{17}$ molybdenium, ${ }^{18}$ nickel, ${ }^{19-21}$ palladium, ${ }^{22}$ platinum, ${ }^{23}$ samarium(III),${ }^{24}$ silver,${ }^{25}$ titanium dioxide, ${ }^{26}$ vanadium,${ }^{27}$ zinc, ${ }^{28,29}$, zirconium, ${ }^{30}$ ruthenium oxide, ${ }^{31}$ terbium, ${ }^{32}$ cerium hexacyanoferrate,${ }^{33}$ neodymium, ${ }^{34}$ gadolinium $^{35}$ or yttrium. ${ }^{36}$ Most of these modified electrodes have been used to reduce the overvoltage, overcome the slow kinetics of many electrode processes and determination of one species as an analytical application. 
Dopamine (DA) is an important kind of neurotransmitter in mammalian central nervous systems. Extreme abnormalities of DA levels cause symptoms of several diseases such as Parkinsonism. ${ }^{37}$ The concentration of neurotransmitters in biological samples varies from species to species, in a wide range of from $10^{-6}$ to $10^{-3} \mathrm{~mol} \mathrm{~L}^{-1} .{ }^{38,39}$ Ascorbic acid (AA) has been used for the prevention and treatment of common cold, mental illness, infertility, cancer and AIDS. ${ }^{40}$ In mammalian brain, AA is present along with several neurotransmitter amines including dopamine. Thus simultaneous determination of DA and AA is a problem of critical importance in the field of neurochemistry and biomedical chemistry. The increasing demand to determine these compounds led to the development of new techniques, among which electrochemical sensors attracted wide attention due to their advantages of simple, inexpensive and fast analysis in combination with high sensitivity and selectivity. ${ }^{41,42}$ Both DA and AA are oxidisable compounds, characteristics which makes their detection possible by electrochemical methods based on anodic oxidation. However, a major problem is that both AA and DA are oxidized at nearly same potential with poor sensitivity at (unmodified) electrodes, which resulted in overlapped voltammetric responses making their discrimination highly difficult. ${ }^{43}$ Electrochemical techniques with modified electrodes have received great interest for neurotransmitters determination in the presence of ascorbic acid as they are more selective and less time consuming and more versatile than those based on other colorimetric or spectrophotometric methods. Therefore, several attempts have been made to construct modified electrodes for the simultaneous determination of DA and AA such as self-assembled monolayer modified electrode, ${ }^{44-46}$ self-assembled bilayer membrane modified glassy carbon electrode,${ }^{47}$ cationic self-assembled monolayer, ${ }^{48}$ enzymebased techniques, ${ }^{49,50}$ organic electron mediators, ${ }^{51,52}$ sol-gel composite electrode, ${ }^{53}$ multi-wall carbon nanotube, ${ }^{54,55}$ lipoic acid-coated carbon fiber microelectrodes,${ }^{56}$ poly(neutral red) modified electrodes, ${ }^{57-59}$ cationic and anionic surfactant modified electrode, ${ }^{60,61}$ carbon paste electrode modified with iron (II) phthalocyanine complexes ${ }^{62}$ and tetrabromo- $p$ benzoquinone modified carbon past electrode. ${ }^{57}$ However, still there is an expanding demand for the development of simple, sensitive, stable, reliable and selective sensors for effective sensing for DA and AA simultaneously. Among the carbon electrodes, the carbon paste electrode (CPE) is of particular importance. Simple and fast preparation, obtaining a new reproducible surface, the low residual current, porous surface and low cost of carbon paste are some advantages of CPEs over all other electrodes. Therefore, the CPE can provide a suitable electrode substrate for preparation of modified electrodes.
In the present work, we prepared a Th-HCF carbon paste electrode and examined its electrochemical behavior using different voltammetric techniques. To the best of our knowledge, there is no report about the preparation of modified electrodes using Th-HCF adduct. We also, studied the catalytic activity on molecules of biological interest, such as DA and AA.

\section{Experimental}

\section{Chemicals}

$\mathrm{Th}\left(\mathrm{NO}_{3}\right)_{4} .5 \mathrm{H}_{2} \mathrm{O}, \mathrm{K}_{4} \mathrm{Fe}(\mathrm{CN})_{6}$, graphite fine powder and liquid paraffin were obtained from Merck and ascorbic acid (AA), dopamine (DA), were obtained from Fluka and used as received. All other chemicals used were of analytical grade. All solutions were prepared with twice distilled water. The buffer solution $\left(0.1 \mathrm{~mol} \mathrm{~L}^{-1}\right)$ was made up from $\mathrm{H}_{3} \mathrm{PO}_{4}+\mathrm{KH}_{2} \mathrm{PO}_{4}$, and the $\mathrm{pH}$ was adjusted with $0.1 \mathrm{~mol} \mathrm{~L}^{-1}$ $\mathrm{H}_{3} \mathrm{PO}_{4}$ and/or $2.0 \mathrm{~mol} \mathrm{~L}^{-1} \mathrm{KOH}$. AA and DA solutions were prepared just prior to use and all experiments were carried out at the ambient temperature of the laboratory $\left(25^{\circ} \mathrm{C}\right)$. All solutions tested were deaerated by passing highly pure nitrogen (99.999\%) before the electrochemical experiments and a continuous flow of nitrogen was maintained over the sample solution during the experiments.

\section{Apparatus}

Cyclic voltammograms were recorded by using Autolab PGSTAT30 Potentiostat/Galvanostat equipped with a frequency response analyzer (FRA4.9) and controlled by general purpose electrochemical system (GPES 4.9) software (Eco Chemie, Utrecht, The Netherlands). The cell used was equipped with a modified carbon paste disk as the working electrode, a glassy carbon electrode as an auxiliary electrode and with an $\mathrm{Ag} / \mathrm{AgCl}$ as a reference electrode. All potentials in the text are quoted versus this reference electrode. A personal computer was used for data storage and processing. The $\mathrm{pH}$ was measured with a Zag Chemie model PTR79 pH/mV-meter (Tehran, Iran).

\section{Preparation of Th-HCF modified CPE (THMCPE)}

To a $20 \mathrm{~mL}$ acidic aliquot of a $0.1 \mathrm{~mol} \mathrm{~L}^{-1}$ aqueous thorium solution was slowly added a $20 \mathrm{~mL}$ potassium hexacyanoferrate solution $\left(0.1 \mathrm{~mol} \mathrm{~L}^{-1}\right)$ with continuous stirring until precipitation was completed. The resulting ion-pair precipitate was isolated by filtration, washed thoroughly with deionized water and dried at $40{ }^{\circ} \mathrm{C}$. The composition of the formed ion pair was confirmed 
as $\mathrm{Th}\left[\mathrm{Fe}(\mathrm{CN})_{6}\right]$ by the chemical analysis. The carbon paste electrode was prepared by hand-mixing of graphite powder, paraffin and Th-HCF ion-pair. The ratio of graphite powder to paraffin and to Th-HCF ion-pair was 70:15:15. The body of the carbon paste-working electrode was a Teflon rod with a hole $(3 \mathrm{~mm}$ diameter and $5 \mathrm{~mm}$ deep) bored at one end for paste filling. Contact was made with a copper wire through the centre of the rod. The modified carbon paste was packed into the hole of the electrode body and levelled off with a spatula. The bare CPE was fabricated by the conventional procedure without Th-HCF ion-pair. The ratio of graphite to paraffin was $70: 30$.

\section{Results and Discussion}

\section{Electrochemical behavior of THMCPE}

The electrochemical behavior of THMCPE was studied using cyclic voltammetry. Cyclic voltammograms of THMCPE in $0.1 \mathrm{~mol} \mathrm{~L}^{-1}$ phosphate buffer solution ( $\mathrm{pH} 3$ ) at different low scan rates are shown in Figure 1-A. As seen, the voltammograms consisted of a pair of well-defined redox peaks with peak-to-peak potential separation $\left(\Delta \mathrm{E}_{\mathrm{p}}=\right.$ $\mathrm{E}_{\mathrm{pa}}-\mathrm{E}_{\mathrm{pc}}$ ) about $67 \mathrm{mV}$ at potential scan rates lower than $60 \mathrm{mVs}^{-1}$. Also, the formal potential $\left(\mathrm{E}^{\mathrm{o}}=\left(\mathrm{E}_{\mathrm{pc}}+\mathrm{E}_{\mathrm{pa}}\right) / 2\right)$ is almost independent of the potential sweep rates below $60 \mathrm{mVs}^{-1}$, suggesting facile charge transfer kinetics over this range of sweep rates. On the other hand, peak currents of the voltammograms are linearly proportional to the scan rate indicating a surface-immobilized redox couple. At potential scan rates higher than $100 \mathrm{mV} \mathrm{s}^{-1}$, the peak separation increases, indicating the limitation arising from charge transfer kinetics (Figure 1-B). Also, the ratio of cathodic to anodic peak currents was almost constant and peak currents are directly proportional to the square root of potential scan rates, as predicted for a diffusion controlled electrode process system (Figure 1-C).

The effect of $\mathrm{pH}$ on the electrochemical behavior of the THMCPE was investigated by cyclic voltammetry in $0.1 \mathrm{~mol} \mathrm{~L}^{-1}$ phosphate buffer solution of various $\mathrm{pH}$ values (2-10) containing $0.1 \mathrm{~mol} \mathrm{~L}^{-1} \mathrm{KCl}$ as supporting electrolyte. The obtained results showed a slightly decrease of the current response with increasing $\mathrm{pH}$ value due to a lower stability of the hexacyanoferrate-Th(IV) association. The mediator coating is stable at $\mathrm{pH}$ lower than 6 .

The stability of THMCPE as the rate of loss of electrochemical activity was examined by repetitive scans in a in $0.1 \mathrm{~mol} \mathrm{~L}^{-1}$ phosphate buffer solution ( $\mathrm{pH} 3$ ). This rate was evaluated as decrease in anodic or cathodic charge in consecutive potential scan cycles. The obtained
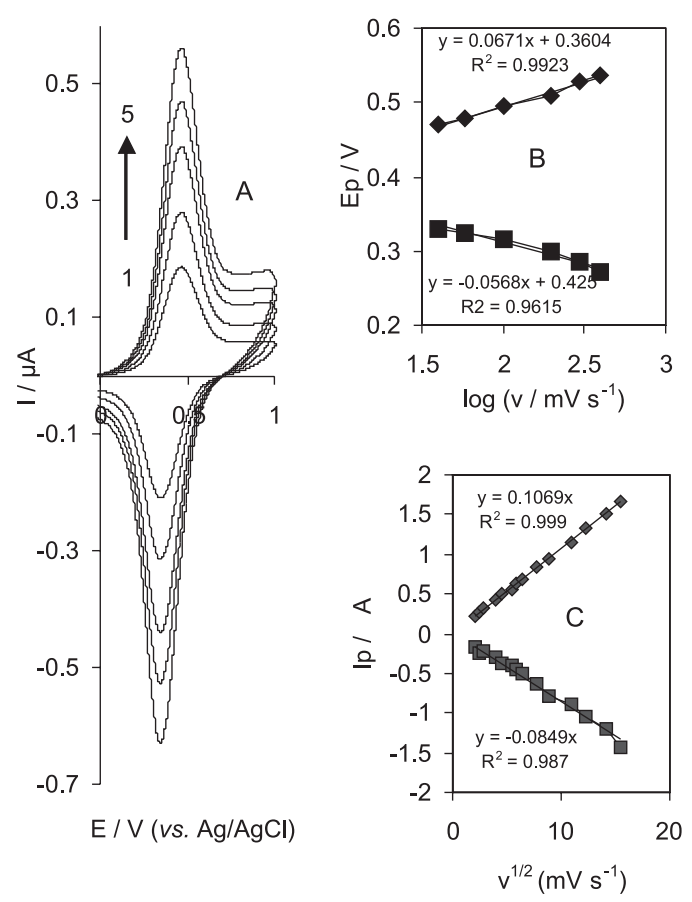

Figure 1. (A) Cyclic voltammograms of THMCPE in $0.1 \mathrm{~mol} \mathrm{~L}^{-1}$ phosphate buffer $(\mathrm{pH} \mathrm{3})$ at various scan rates: voltammograms $1-5$ is corresponding to 4, 8, 12, 16 and $20 \mathrm{mV} \mathrm{s}^{-1}$ scan rates, respectively. Inset (B): variation of $\mathrm{E}_{\mathrm{p}}$ versus the logarithm of the high scan rates. Inset $(\mathrm{C})$ : Variations of $\mathrm{I}_{\mathrm{p}} v s . v^{1 / 2}$.

results showed that the anodic and cathodic peak currents of THMCPE decrease 5\% after 100 cycles at potential scan rates $20-50 \mathrm{mV} \mathrm{s}^{-1}$ without any considerable change in potential peak separation. Furthermore, no significance change in activity of THMCPE was observed after almost 40 times use within two months.

An approximate estimation of the surface coverage of the electrode was made by adopting the method used by Laviron. ${ }^{63}$ According to this method, total amount of charge (Q) is related to the surface concentration of electroactive species, $\Gamma^{*}$, by the following equation:

$\Gamma^{*}=\frac{\mathrm{Q}}{\mathrm{nFA}}$

Where $\mathrm{n}$ represents the number of electrons involved in reaction, $\mathrm{A}$ is the surface area of the electrode, $\left.\Gamma^{*}(\mathrm{~mol} \mathrm{~cm})^{-2}\right)$ is the surface coverage and $\mathrm{Q}$ is total amount of charge which can be obtained from the integration of cyclic voltammetry peak and F is Faraday constant. The average amount of electrode surface coverage for anodic peaks recorded at $60 \mathrm{mV} \mathrm{s}^{-1}$ (as a low scan rate) with surface area $0.125 \mathrm{~cm}^{2}$ was $7.06 \times 10^{-10} \mathrm{~mol} \mathrm{~cm} \mathrm{~cm}^{-2}$. At higher potential scan rates, the peak separation increases and the apparent coverage is slightly diminished probably due to drop in charge transfer through a modified layer, which becomes rate-limiting at higher scan rates. 
The transfer coefficient, $\alpha$, and the heterogeneous rate constant, $\mathrm{k}_{\mathrm{s}}$, of a surface-confined redox couple can be evaluated from cyclic voltammetric experiments and using the variation of anodic and cathodic peak potentials with scan rate, according to the procedure of Laviron. ${ }^{57}$ The obtained results showed that the $E_{p}$ values are linearly proportional to $\log \mathrm{v}$, for scan rates higher than $100 \mathrm{mV} \mathrm{s}^{-1}\left(\Delta \mathrm{E}_{\mathrm{p}}>200 / \mathrm{n} \mathrm{mV}\right.$ see Figure 1, inset B). Under these conditions, the following equations could be used to determine the electron transfer rate constant between hexacyanoferrate Th-HCF and CPE :

$$
\begin{aligned}
& \mathrm{E}_{\mathrm{pa}}=\mathrm{E}_{\mathrm{o}}+A \ln \left[\frac{(1)-\alpha}{m}\right] \\
& \mathrm{E}_{\mathrm{pc}}=\mathrm{E}_{\mathrm{o}}+B \ln \left[\frac{\alpha}{m}\right] \\
& \log k_{s}=\alpha \log (1-\alpha)+(1-\alpha) \log \alpha-\log \left(\frac{R T}{n F V}\right)-\alpha(1-\alpha)\left(\frac{n F \Delta E_{p}}{2.3 R T}\right)
\end{aligned}
$$

where: $A=\frac{R T}{(1-\alpha) n F}, B=\frac{R T}{\alpha n F}, \mathrm{~m}=\left(\frac{R T}{F}\right)\left(\frac{K_{s}}{n V}\right)$

According to equations 2 and 3 , the plot of $\mathrm{E}_{\mathrm{p}}-\mathrm{E}_{\mathrm{o}}=\mathrm{f}(\log \mathrm{v})$ yields two straight lines with a slope equal to $2.3 \mathrm{RT} / \alpha \mathrm{nF}$ for the cathodic peak and 2.3 RT/ $(1-\alpha) \mathrm{nF}$ for anodic peak. Using these slopes and also equation 4 , the values of $\alpha$ and $\mathrm{k}_{\mathrm{s}}$ were found to be 0.47 and $3.1 \pm 0.1 \mathrm{~s}^{-1}$.

\section{Electrocatalytic oxidation of $A A$}

Figure 2 shows the $\mathrm{CV}$ s obtained from the oxidation of AA at bare CPE and THMCPE. The curves (A) and (B) are corresponding to $0.1 \mathrm{~mol} \mathrm{~L}^{-1}$ buffer phosphate solution $(\mathrm{pH} 3)$ in the absence and presence of $3 \mathrm{~b} \times 10^{-4} \mathrm{~mol} \mathrm{~L}^{-1} \mathrm{AA}$,

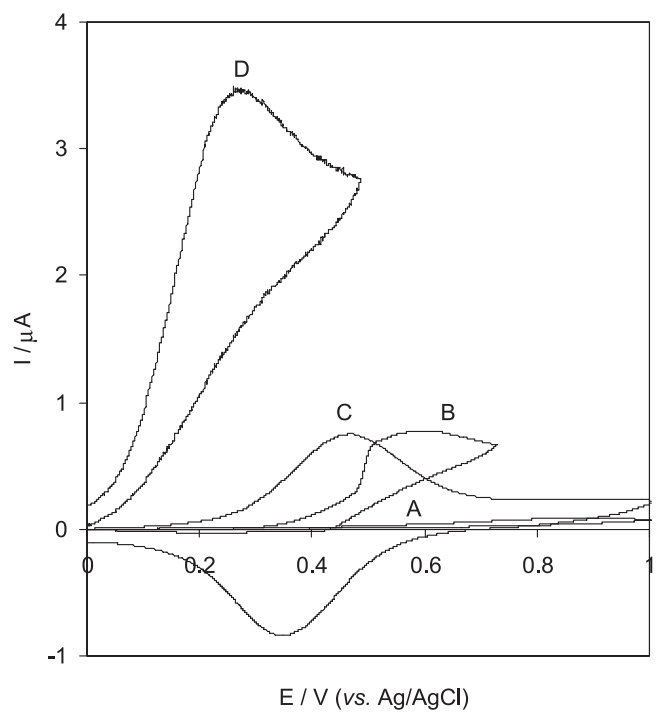

Figure 2. $\mathrm{CV}$ s for (A) bare electrode, (B) $3 \times 10^{-4} \mathrm{~mol} \mathrm{~L}^{-1} \mathrm{AA}$ at bare electrode, (C) THMCPE, (D) $3 \times 10^{-4} \mathrm{~mol} \mathrm{~L}^{-1} \mathrm{AA}$ at THMCPE in $0.1 \mathrm{~mol} \mathrm{~L}^{-1}$ phosphate buffer ( $\mathrm{pH}$ ); scan rate: $20 \mathrm{mV} \mathrm{s}^{-1}$. respectively, at the bare CPE. The curve (C) corresponds to THMCPE and curve (D) corresponds to oxidation of $3 \times 10^{-4} \mathrm{~mol} \mathrm{~L}^{-1} \mathrm{AA}$ at the THMCPE. As can be seen, at the bare electrode, the $\mathrm{CV}$ exhibited a broad peak at potential of $590 \mathrm{mV}$ with poor current response for AA oxidation. In contrast, at the THMCPE, the oxidation current increased greatly at a reduced peak potential of $260 \mathrm{mV}$ and the corresponding cathodic peak disappeared on the reverse scan of potential. The anodic peak current increased with the increase in the concentration of AA. The significant negative shift in the peak potential about $330 \mathrm{mV}$ and the enhanced current response observed with the THMCPE compared to bare $\mathrm{CPE}$ indicate a strong electrocatalytic effect of $\mathrm{Fe}(\mathrm{CN}){ }_{6}^{3-} / \mathrm{Fe}(\mathrm{CN}){ }_{6}^{4-}$ redox couple in the THMCPE towards the oxidation of AA.

\section{Electrocatalytic oxidation of DA}

Electrocatalytic activity of the bare electrode and the THMCPE, were obtained in $0.1 \mathrm{~mol} \mathrm{~L}^{-1}$ phosphate buffer $(\mathrm{pH} 3)$ in presence and absence of $3 \times 10^{-4} \mathrm{~mol} \mathrm{~L}^{-1} \mathrm{DA}$ were presented in Figure 3. Cyclic voltammogramms (A) and (B) show the behavior of bare electrode in the presence and absence of $3 \times 10^{-4} \mathrm{~mol} \mathrm{~L}^{-1} \mathrm{DA}$ and cyclic voltammograms (C) and (D) were obtained for same solutions using THMCPE, respectively. From the obtained $\mathrm{CVs}$, it can be observed that at the THMCPE, the oxidation current increased greatly with a decrease in oxidation potential about $200 \mathrm{mV}$ in comparison to bare CPE. These observations showed an efficient electrocatalytic activity for the oxidation of DA using proposed chemically modified carbon paste electrode.

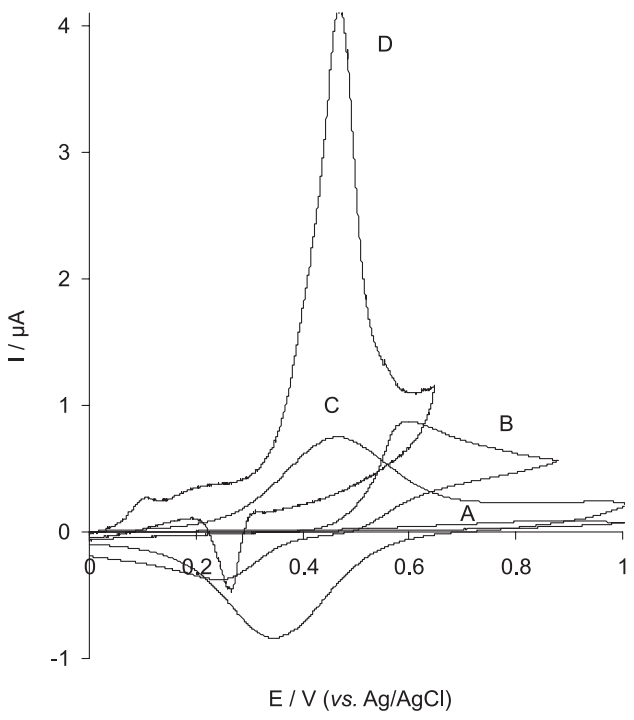

Figure 3. CVs of : (A) bare electrode, (B) $3 \times 10^{-4} \mathrm{~mol} \mathrm{~L}^{-1} \mathrm{DA}$ at bare electrode, (C) THMCPE, (D) $3 \times 10^{-4} \mathrm{~mol} \mathrm{~L}^{-1} \mathrm{DA}$ at THMCPE in $0.1 \mathrm{~mol} \mathrm{~L}^{-1}$ phosphate buffer ( $\mathrm{pH} 3$ ); scan rate: $20 \mathrm{mV} \mathrm{s}^{-1}$. 


\section{Effect of $p H$ on the oxidation of $A A$ and $D A$}

The influence of solution $\mathrm{pH}$ on the electrochemical response of the THMCPE towards the oxidation of AA and DA was studied in $\mathrm{pH}$ range from 2 to 9 . Figures $4 \mathrm{~A}$ and $4 \mathrm{~B}$ show the variation of peak potential and peak current with respect to changes in the $\mathrm{pH}$ of the electrolyte, respectively. In both figures, the curve (a) corresponds to $3 \times 10^{-3} \mathrm{~mol} \mathrm{~L}^{-1} \mathrm{AA}$ and (b) corresponds to $1 \times 10^{-3} \mathrm{~mol} \mathrm{~L}^{-1}$ DA. It was observed that the peak potential for both AA and DA shifted negatively with the increase in $\mathrm{pH}$ of the electrolyte. Also, the current responses for AA and DA oxidation were higher at acidic $\mathrm{pH}$ conditions. As can be seen from figures, while the difference between potential shifts for AA and DA oxidation were nearly constant at all tested $\mathrm{pH}$ (see Figure 4-A, curves a and b), the obtained current responses were diminished with the increase in $\mathrm{pH}$ of the electrolyte. On the other hand, the proposed modified electrode showed excellent stability as well as reproducible signals in acidic solutions. Therefore, a $\mathrm{pH}$ of 3 was chosen for oxidation studies of AA and DA with THMCPE.
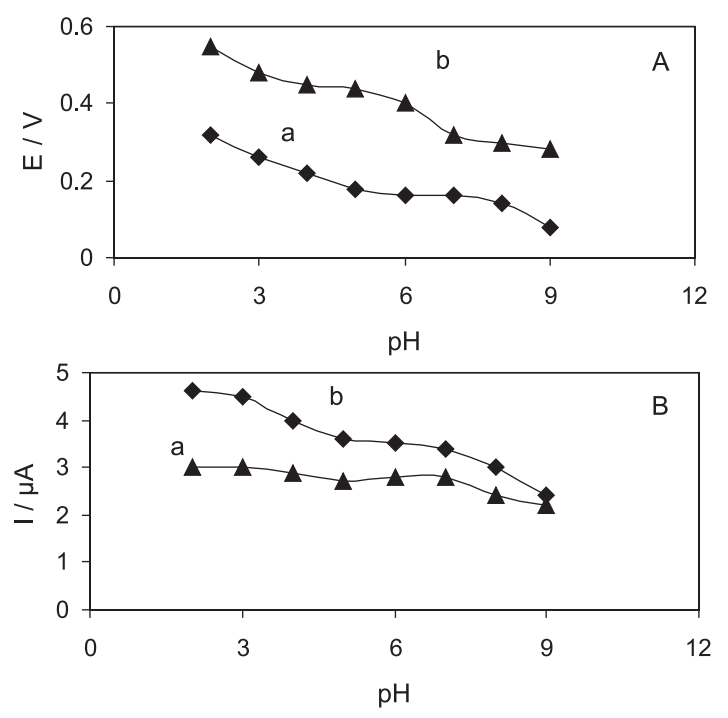

Figure 4. Effect of $\mathrm{pH}$ on (A) peak potential and (B) peak current for the oxidation of (a) $3 \times 10^{-4} \mathrm{~mol} \mathrm{~L}^{-1} \mathrm{AA}$ and (b) $5 \times 10^{-5} \mathrm{~mol} \mathrm{~L}^{-1} \mathrm{DA}$ at the THMCPE, scan rate: $20 \mathrm{mV} \mathrm{s}^{-1}$.

\section{Chronoamperometric studies of AA and DA oxidation}

Double potential step chronoamperometry, as well as other electrochemical methods was employed for investigation of electrochemical process at the chemically modified electrodes. The current-time curves of THMCPE were obtained by setting the working electrode potential at $0.80 \mathrm{~V}$ (at the first potential step) and at $0.00 \mathrm{~V}$ (at second potential step) vs. $\mathrm{Ag} / \mathrm{AgCl}$ for the various concentration of ascorbic acid and dopamine in buffered aqueous solutions ( $\mathrm{pH} \mathrm{3}$ ) and also for modified electrode in the absence of AA and DA. For an electroactive material with a diffusion coefficient (D), the current corresponding to the electrochemical reaction (under diffusion controlled) is described by Cottrell equation: ${ }^{64}$

$\mathrm{I}=\mathrm{nFAC}_{0} \mathrm{D}^{1 / 2} \Pi^{-1 / 2} \mathrm{t}^{-1 / 2}$

Where D is apparent the diffusion coefficient $\left(\mathrm{cm}^{2} \mathrm{~s}^{-1}\right)$ and $\mathrm{C}_{0}$ is the apparent bulk concentration $\left(\mathrm{mol} \mathrm{cm}{ }^{-3}\right)$, respectively. Diffusion coefficient is easily calculated from the slope of the plot of I vs. $\mathrm{t}^{-1 / 2}$. Chronoamperograms using modified electrode for solution containing AA and/or DA represented a typical $\mathrm{I}^{-\mathrm{t}^{-1 / 2}}$ curves which indicates that the observed currents have a diffusion control nature. The mean value of the $\mathrm{D}$ for ascorbic acid and dopamine were found $4.06 \times 10^{-5}$ and $4.43 \times 10^{-5}\left(\mathrm{~cm}^{2} \mathrm{~s}^{-1}\right)$, respectively.

\section{Simultaneous determination of $D A$ and $A A$}

Figure 5 shows the $\mathrm{CV}$ s of a mixture of AA and DA at bare CPE and at THMCPE in $0.1 \mathrm{~mol} \mathrm{~L}^{-1}$ phosphate buffer solution ( $\mathrm{pH} 3$ ). In this figure, the curves (a) and (b) correspond to the oxidation of a mixture of $6 \times 10^{-4} \mathrm{~mol} \mathrm{~L}^{-1}$ AA and $3 \times 10^{-4} \mathrm{~mol} \mathrm{~L}^{-1} \mathrm{DA}$ at bare electrode and THMCPE, respectively. As can be seen, a poor current response was observed at the bare CPE in the presence of a mixture of DA and AA. In contrast, two well-defined anodic peaks at the potential of 260 and $470 \mathrm{mV}$ were observed for the oxidation of AA and DA, respectively, at the THMCPE. The difference between the two peak potentials is about $190 \mathrm{mV}$ and the current response increased with the increase in the concentration of AA and DA. Figure 6 shows the CVs of oxidation peak of various concentrations of AA in presence of $3 \times 10^{-4} \mathrm{~mol} \mathrm{~L}^{-1} \mathrm{DA}$. The curves (a), (b) and (c) correspond to the presence of $1 \times 10^{-4}, 3 \times 10^{-4}$ and $6 \times 10^{-4} \mathrm{~mol} \mathrm{~L}^{-1} \mathrm{AA}$. As can be seen, while the current response at the DA oxidation peak is fix, the current response at the AA peak increased with the increase in the concentration of AA. Similarly, Figure 7 shows the CVs recorded for the solutions containing various concentrations of DA in the presence of $3 \times 10^{-4} \mathrm{~mol} \mathrm{~L}^{-1} \mathrm{AA}$. As can be seen from the curves (a), (b) and (c) correspond to the oxidation of $5 \times 10^{-5}, 1 \times 10^{-4}$ and $3 \times 10^{-4} \mathrm{~mol} \mathrm{~L}^{-1} \mathrm{DA}$, the current response at the DA oxidation peak increased with the increase in the concentration of DA without any change in the AA peak. It should be noted that in contrast with the majority of the electrochemical studies reported in literature for the simultaneous determination of AA and DA, no shift in the potential peaks of AA or DA was observed in all mixed solutions using the proposed modified electrode. 
These results indicated that the THMCPE have an excellent catalytic activity for simultaneous determination of AA and DA at reduced and well-separated peak potentials with enhanced sensitivity. This ability to measure AA and DA in a mixture has significant attraction in biological and chemical research.

\section{Amperometric determination of $A A$ and $D A$}

Typical amperometric signals were obtained by successive addition of AA to continuously stirred phosphate buffer solution ( $\mathrm{pH} 3$ ). Figure 8-A shows a typical

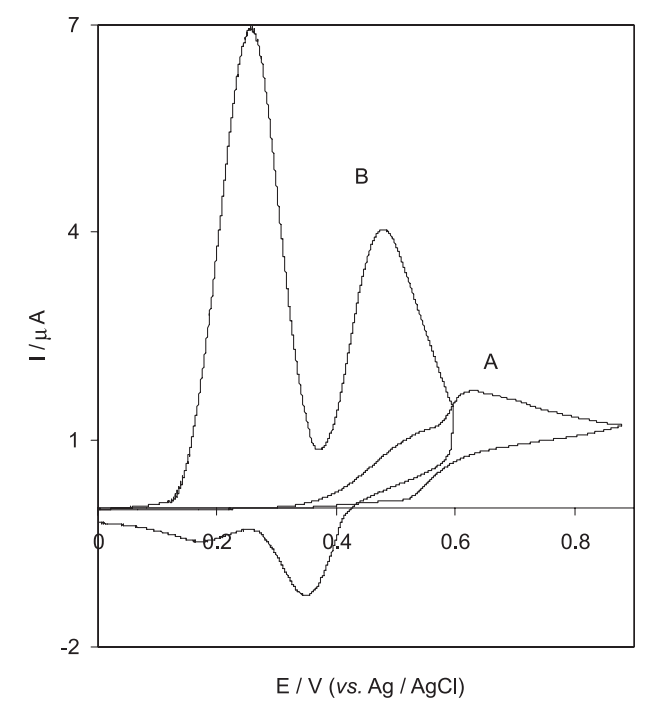

Figure 5. CVs for the oxidation of $6 \times 10^{-4} \mathrm{~mol} \mathrm{~L}^{-1} \mathrm{AA}$ in presence $3 \times$ $10^{-4} \mathrm{~mol} \mathrm{~L}-1$ DA at (A) bare electrode and (B) THMCPE in $0.1 \mathrm{~mol} \mathrm{~L}^{-1}$ phosphate buffer ( $\mathrm{pH}$ 3); scan rate: $20 \mathrm{mV} \mathrm{s}^{-1}$.

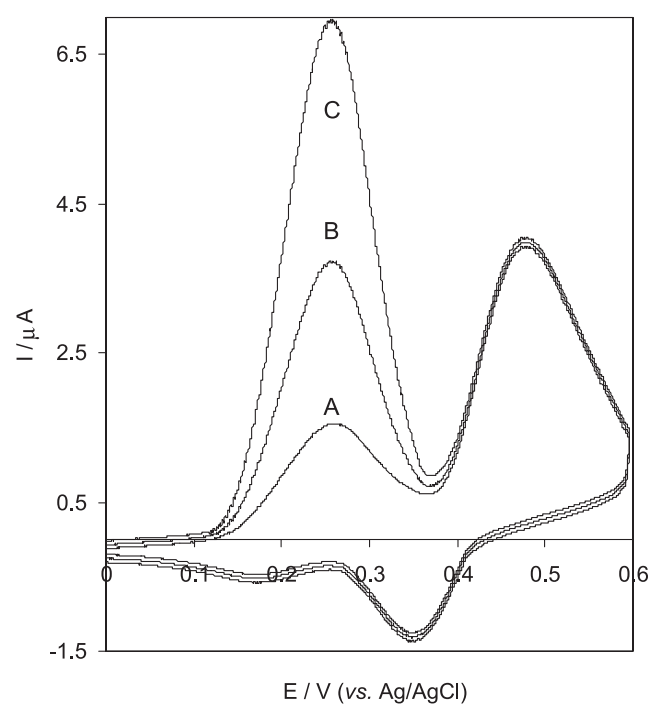

Figure 6. CVs for the oxidation of (A) $1 \times 10^{-4} \mathrm{~mol} \mathrm{~L}^{-1}$, (B) $3 \times 10^{-4} \mathrm{~mol} \mathrm{~L}^{-1}$ and (C) $6 \times 10^{-4} \mathrm{~mol} \mathrm{~L}^{-1} \mathrm{AA}$ in presence of $1 \times 10^{-4} \mathrm{~mol} \mathrm{~L}^{-1} \mathrm{DA}$ at THMCPE in $0.1 \mathrm{~mol} \mathrm{~L}^{-1}$ phosphate buffer (pH 3); scan rate: $20 \mathrm{mV} \mathrm{s}^{-1}$.

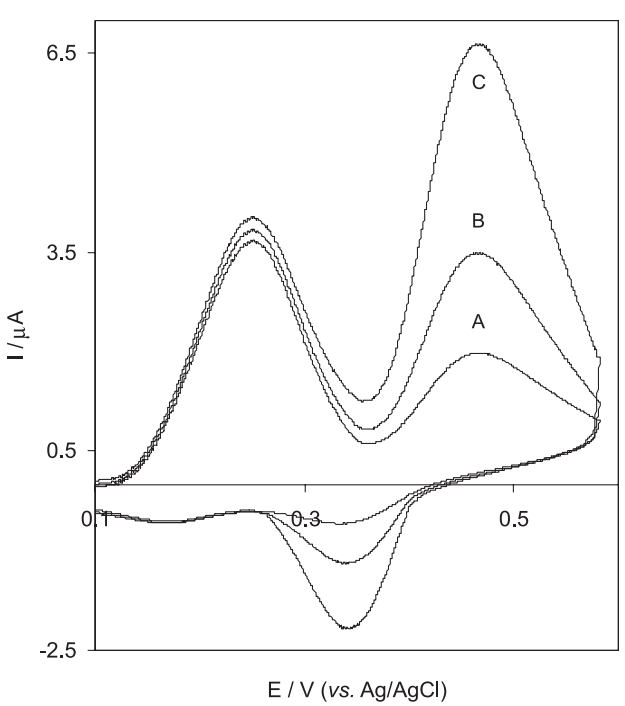

Figure 7. CVs for the oxidation of (A) $5 \times 10^{-5} \mathrm{~mol} \mathrm{~L}^{-1}$, (B) $1 \times 10^{-4} \mathrm{~mol} \mathrm{~L}^{-1}$ and (C) $3 \times 10^{-4} \mathrm{~mol} \mathrm{~L}^{-1} \mathrm{DA}$ in presence of $3 \times 10^{-4} \mathrm{~mol} \mathrm{~L}^{-1} \mathrm{AA}$ at THMCPE in $0.1 \mathrm{~mol} \mathrm{~L}^{-1}$ phosphate buffer ( $\left.\mathrm{pH} 3\right)$; scan rate: $20 \mathrm{mV} \mathrm{s}^{-1}$.

amperometric response obtained at a fixed potential of $300 \mathrm{mV}$ for successive addition of $250 \mu \mathrm{mol} \mathrm{L}^{-1} \mathrm{AA}$. The response time was about $5 \mathrm{~s}$ and the obtained currents using THMCPE were 5-6 times larger than that on bare electrode at the same condition. Figure 8-B shows the calibration graph for determination of a linear response to AA in the concentration range from $1 \times 10^{-5}$ to $2 \times 10^{-3} \mathrm{~mol} \mathrm{~L}^{-1}$ with a correlation coefficient of 0.9953 . When the ratio of signal to noise is 3 the detection limit (LOD) for AA was $5.6 \mu \mathrm{mol} \mathrm{L}^{-1}$. Similarly, Figure 9-A depicts the amperometric response for DA. The applied voltage was at $500 \mathrm{mV}$ for successive addition of $180 \mu \mathrm{mol} \mathrm{L}{ }^{-1}$ DA. The THMCPE exhibited rapid response to the changes in the concentration of DA (less than $6 \mathrm{~s}$ ). Figure 9-B presents linear response to DA in the concentration range from $8 \times 10^{-6}$ to $2 \times 10^{-3} \mathrm{~mol} \mathrm{~L}^{-1}$. Correlation coefficient was obtained 0.9904 with LOD $4.7 \mu \mathrm{mol} \mathrm{L}{ }^{-1}$ when $\mathrm{S} / \mathrm{N}$ was 3 . The proposed electrode showed a good repeatable and reproducible response for DA and AA. The peak current values for DA and AA were detected with a relative standard deviations of $3.2 \%$ and $3.5 \%$, respectively. It must be noted that we evaluated the electrocatalytic oxidation of some oxidisable inorganic ions such as thiosulfate, nitrite as well as some inorganic and organic molecules such as hydrazine and uric acid using proposed probe. In all cases no significant electrocatalytic effect were observed.

\section{Conclusions}

The electrochemical properties of THMCPE were studied as new chemically modified carbon paste electrode. The THMCPE showed an excellent electrocatalytic activity towards AA and DA and applied for the simultaneous 


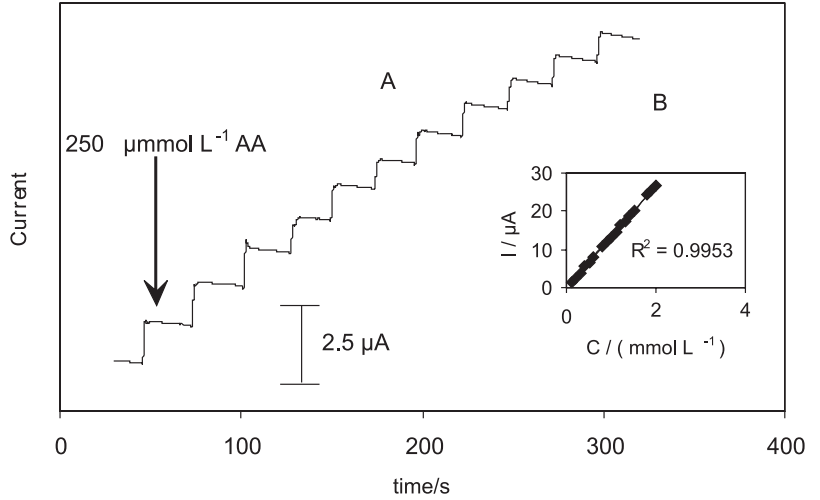

Figure 8. Inset (A) Current signal monitored as a function of time at the THMCPE for the successive addition of $250 \mu \mathrm{mol} \mathrm{L}^{-1}$ AA to the stirring $0.1 \mathrm{~mol} \mathrm{~L}^{-1}$ phosphate buffer $(\mathrm{pH} \mathrm{3})$; stirring rate : $350 \mathrm{rpm}$. Inset (B) Calibration plot.

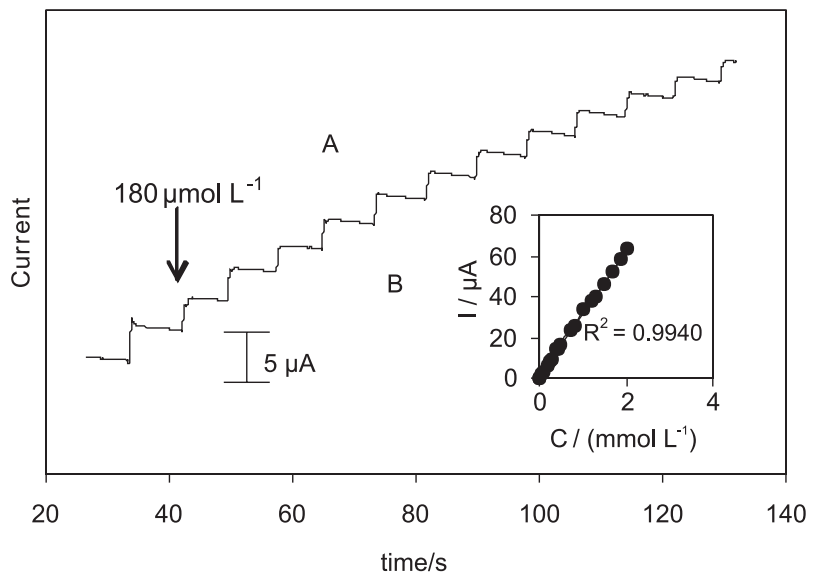

Figure 9. Inset (A) Current signal monitored as a function of time at THMCPE for the successive addition of $180 \mu \mathrm{mol} \mathrm{L}^{-1} \mathrm{DA}$ to the stirring $0.1 \mathrm{~mol} \mathrm{~L}^{-1}$ phosphate buffer ( $\mathrm{pH} 3$ ); stirring rate : $350 \mathrm{rpm}$. Inset (B) Calibration plot.

determination of ascorbic acid and dopamine in phosphate buffer ( $\mathrm{pH} 3$ ) with good sensitivity and selectivity. The oxidation of AA at the THMCPE occurred at the potential of $270 \mathrm{mV}$ with a great increase in the peak current compared to that of the bare carbon paste electrode. Electrocatalytic oxidation of DA was observed at the potential of $470 \mathrm{mV}$ with a great increase in response peak current toward bare CPE. The voltammetric signals of AA and DA were obtained in two well-defined peaks with a peak separation of $200 \mathrm{mV}$. A favourable electrocatalytic reaction between the THMCPE and AA and DA shifted their oxidation potential to a less positive potential. Although, the detection limit of proposed method for DA and AA is slightly higher than the some reported works in the literature, but the electrocatalytic ability toward AA and DA in acidic media (pH 3) with wider linear range, good reproducibility and stability are the most important aspect of the proposed modified electrode in comparison to other reports.

\section{References}

1. Neff, V. D.; J. Electrochem. Soc. 1978, 125, 886.

2. Itaya, K.; Uchida, I; Neff, V.D.; Acc. Chem. Res. 1986, 19, 162.

3. Luangdilok, C. H.; Arnet, D. J.; Bocarsly, A. B.; Wood, R; Langmuir 1992, 8, 650.

4. Lin, M. S.; Shih, W. C.; Anal. Chim. Acta 1999, 381, 183.

5. Xu, F.; Gao, M.; Wang, L.; Zhou, T.; Jin, L.; Jin, J.; Talanta 2002, 58, 427.

6. Kulseza, P. J.; Malik, M. A.; Berrettoni, M.; Giorgetti, M.; Zamponi, S.; Schmidt, R.; Marassi, R.; J. Phys. Chem. B 1998, $102,1870$.

7. Kulseza, P. J.; Zamponi, S.; Malik, M.A.; Berrettoni, M.; Wolkiewicz, A.; Marassi, R.; Electrochim. Acta 1998, 43, 919.

8. Cai, C. X.; Ju, H. X.; Chen, H. Y.; J. Electroanal. Chem. 1995, 397, 185.

9. Wang, J.; Zhang, X.; Chen, L.; Electroanalysis 2000, 12, 1277.

10. Wang, J.; Zhang, X.; Prakash, M.; Anal. Chim. Acta 1999, 395, 11.

11. Kahlert, H.; Retter, U.; Lohse, H.; Siegler, K.; Scholz, F.; J. Phys. Chem. B 1998, 102, 8757.

12. Siperko, L. M.; Kuwana, T.; Electrochim. Acta 1987, 32, 765.

13. Eftekhari, A.; J. Electrochem. Soc. 2004, 151, 297.

14. Tacconi, N. R. D.; Rajeshwar, K.; Lezna, R. O.; J. Electroanal. Chem. 2001, 500, 270.

15. Cataldi, T. R. I.; Benedetto, G. E. D.; Bianchini, A.; J. Electroanal. Chem. 1998, 448, 111.

16. Liu, S. Q.; Chen, H. Y.; J. Electroanal. Chem. 2002, 528, 190.

17. Wang, P.; Jiang, X.; Zhang, W.; Zhu, G.; J. Solid State Electrochem. 2001, 5, 369.

18. Dong, S.; Jiu, Z.; J. Electroanal. Chem. 1988, 256, 193.

19. Vittal, R.; Gomathi, H.; Rao, G. P. ; Electrochim. Acta 2000, 45, 2083.

20. Narayanan, S. S.; Scholz, F.; Electroanalysis 1999, 11, 465.

21. Pournaghi-Azar, M. H.; Razmi-Nerbin, H.; J. Electroanal Chem. 1998, 456, 83.

22. Pournaghi-Azar, M. H.; Dastangoo, H.; J. Electroanal. Chem. 2002, 523, 26.

23. Liu, S.; Li, H.; Jiang, M.; Li, P.; J. Electroanal. Chem. 1997, 426, 27.

24. Wu, P.; Cai, C.; J. Solid State Electrochem 2004, 8, 538.

25. Eftekhari, A.; Anal. Lett. 2001, 34, 541.

26. Mishma, Y.; Motonaka, J.; Maruyama, K.; Ikeda, S.; Anal. Chim. Acta, 1998, 358, 291.

27. Liu, C.; Dong, S.; Electroanalysis 1997, 9, 838.

28. Eftekhari, A.; J. Electroanal. Chem. 2002, 537, 59.

29. Joseph, J.; Gomathi, H.; Rao, G.P.; J. Electroanal. Chem. 1997, $431,231$. 
30. Liu, S. Q.; Chen, H. Y.; J. Electroanal. Chem. 2001, 502, 197.

31. Paixão, T. R. L. C.; Bertotti, M.; J. Pharm. Biomed. Anal. 2007, $46,528$.

32. Sheng, Q.; Yu; H.; Zheng, J.; J. Electroanal. Chem. 2007, 606, 39.

33. Fang, B.; Wei, Y.; Li, M.; Wang, G.; Zhang, W.; Talanta 2007, $72,1302$.

34. Sheng, Q. L.; Yu, H.; Zheng, J.B.; Electrochim. Acta 2007, 52, 4506.

35. Shi, Y.; Wu, P.; Du, P.; Cai, C.; Acta Physico-Chimica Sinica 2006, 22, 1227.

36. Róka, A.; Varga, I.; Inzelt, G.; Electrochim. Acta 2006, 51, 6243.

37. Wightman, R. M.; May, L. J.; Michael, A.C.; Anal. Chem, 1988, 60, 69A.

38. Capella, P.; Ghasemzadech, B.; Mitchell, K.; Adams, R. N.; Electroanalysis 1990, 2, 175.

39. Adams, R. N.; Anal. Chem. 1976, 48, 1126A.

40. Arrigoni, O.; Tullio, C. D.; Biochim. Biophys. Acta, 2002, 1569 , 1.

41. Baldwin, R. P.; Thomsen, K.N.; Talanta, 1991, 38, 1.

42. Wring, S. A.; Hart, J. P.; Analyst 1992, 117, 1215.

43. O’Neill, R. D.; Analyst 1994, 119, 767.

44. Malem, F.; Mandler, D.; Anal. Chem. 1993, 65, 37.

45. Karimi-Shervedani, R.; Bagherzadeh, M.; Mozaffari, S. A.; Sens. Actuator. B 2006, 115, 614.

46. Raj, C. R.; Ohsaka, T.; J. Electroanal. Chem. 2003, 540, 69.

47. Lin, X.; Gong, J.; Anal. Chim. Acta 2004, 507, 255.

48. Raj, C. R.; Tokuda, K.; Ohsaka, T.; Biochemistry 2001, 53, 183.
49. Nagy, G.; Rice, M. E.; Adams, R. N.; Life Sci. 1982, 31, 2611.

50. Forzani, E. S.; Rivas, G. A.; Solis, V. M.; J. Electroanal. Chem. 1997, 435, 77.

51. Khoo, S. B.; Chen, F.; Anal. Chem. 2002, 74, 5734.

52. Shahrokhian, S.; Ghalkhani, M.; Electrochim. Acta 2006, 51, 2599.

53. Salimi, A.; Mamkhezri, H.; Hallaj, R.; Talanta 2006, 70, 823.

54. Zhang, M.; Gong. K.; Zhang, H.; Mao, L.; Biosens. Bioelectronic 2005, 20, 1270 .

55. Kumar, S. S.; Mathiyarasu, J.; Phani, K. L. N.; J. Solid State Electrochem. 2006, 10, 905.

56. He, P.; Yu, Y.; Fang, Y.; Chin. J. Anal. Chem. 1996, 24, 407.

57. Aguilar, R.; Davila, M. M.; Elizalde, M. P.; Mattusch, J.; Wennrich, R.; Electrochim. Acta 2004, 49, 851.

58. Roy, P. R.; Okajima, T.; Ohsaka, T.; Bioelectrochemistry 2003, $59,11$.

59. Sun, Y.; Ye, B.; Zhary, W.; Zhou, X.; Anal. Chim. Acta 1998, 363,75 .

60. Liu, Y. J.; Zhang, Z. H.; Nie, L. H.; Yao, S.Z.; Electrochim. Acta 2003, 48, 2823.

61. Lenys, F.; Hermes, C.; Electrochim. Acta 2003, 50, 1233.

62. Oni, J.; Nyokong, T.; Anal. Chim. Acta 2001, 434, 9.

63. Laviron, E.; J. Electroanal. Chem. 1979, 101, 19.

64. Bard, A. J.; Faulkner, L.R.; Electrochemical Methods, Fundamentals and Applications, Wiley: New York, 2001.

Received: August 26, 2007 Web Release Date: August 28, 2008 